\title{
GCU
}

Glasgow Caledonian

University

University for the Common Good

\section{Exploring the invasion of rangelands by Acacia mearnsii (black wattle): biophysical characteristics and management implications}

Gwate, Onalenna; Mantel, Sukhmani K.; Finca, Andiswa; Gibson, Lesley A.; Munch, Zahn; Palmer, Anthony R.

Published in:

African Journal of Range and Forage Science

DOI:

10.2989/10220119.2016.1271013

Publication date:

2016

Document Version

Author accepted manuscript

Link to publication in ResearchOnline

Citation for published version (Harvard):

Gwate, O, Mantel, SK, Finca, A, Gibson, LA, Munch, Z \& Palmer, AR 2016, 'Exploring the invasion of rangelands by Acacia mearnsii (black wattle): biophysical characteristics and management implications', African Journal of Range and Forage Science, vol. 33, no. 4, pp. 265-273 .

https://doi.org/10.2989/10220119.2016.1271013

\section{General rights}

Copyright and moral rights for the publications made accessible in the public portal are retained by the authors and/or other copyright owners and it is a condition of accessing publications that users recognise and abide by the legal requirements associated with these rights.

Take down policy

If you believe that this document breaches copyright please view our takedown policy at https://edshare.gcu.ac.uk/id/eprint/5179 for details

of how to contact us. 
1 Exploring the invasion of rangelands by Acacia mearnsii (black wattle): biophysical 2 characteristics and management implications

3 Onalenna Gwate ${ }^{1, *}$

4 E-mail: onalennag37@gmail.com

5 Sukhmani K. Mantel ${ }^{1}$

$6 \quad$ E-mail: $\underline{\text { s.mantel@,ru.ac.za }}$

7 Andiswa Finca ${ }^{2}$

$8 \quad$ E-mail: fincaa@arc.agric.za

$9 \quad$ Lesley A. Gibson ${ }^{3}$

10 E-mail: lamjgibson@gmail.com

11 Zahn Munch ${ }^{4}$

12 Email: zmunch@sun.ac.za

13 Anthony R. Palmer ${ }^{1,2}$

14 E-mail: palmert@arc.agric.za

$15{ }^{1}$ Institute for Water Research, Rhodes University, P.O. Box 94, Grahamstown 6140, South 16 Africa

$17{ }^{2}$ Agricultural Research Council-Animal Production Institute, P.O. Box 101, Grahamstown, 18 6140, South Africa

$19{ }^{3}$ Department of Construction and Surveying, Glasgow Caledonian University, Cowcaddens

20 Road, Glasgow, G40BA, Scotland, United Kingdom

$21{ }^{4}$ Department of Geography and Environmental Studies, University of Stellenbosch, P. Bag 22 X1, Matieland, 7602, South Africa

23 Corresponding author, email: onalennag37@gmail.com 


\section{Abstract}

Australian Acacias have spread to many parts of the world. In South Africa, species such as A. mearnsii and A. dealbata are invasive. Consequently, more effort has focused on their clearing. In a context of increasing clearing costs, it is crucial to develop innovative ways of managing invasions. Our aim was to understand the biophysical properties of $A$. mearnsii in grasslands as they relate to grass production and to explore management implications. Aboveground biomass (AGB) of A. mearnsii was determined using a published allometric equation in invaded grasslands of the north Eastern Cape, South Africa. The relationships among the A. mearnsii leaf area index (LAI), Normalized Difference Vegetation Index (NDVI) and AGB were investigated. The influence of $A$. mearnsii LAI and terrain slope on grass cover was also investigated. Strong linear relationships between NDVI, LAI and AGB were developed. Acacia mearnsii canopy adversely impacted grass production more than terrain slope $(\mathrm{p}<0.05)$ and when LAI approached 2.1, grass cover dropped to below $10 \%$ in infested areas. Reducing A. mearnsii canopy could promote grass production while encouraging carbon sequestration. Given the high AGB and clearing costs, it may be prudent to adopt the 'novel ecosystems' approach in managing infested landscapes.

Key words: grassland, invasive plants, landscape ecology, rangeland condition 
Introduction

Invasive Alien Plants (IAPs) are a major force for global change as they often alter the structure and functioning of ecosystems. Australian acacias (wattles) have been transported to different parts of the world (mainly between $35^{\circ}$ North and $40^{\circ}$ South) through various mechanisms such as transfer, diffusion and dispersal (Kull et al. 2011; Le Maitre et al. 2011). They often become invasive in their new environments especially when growing outside plantations. The concomitant mix of carbon and nitrogen fertilization as well as the dynamics in land use affect resource distribution and amplify their invasiveness (Simberloff et al. 2013) and general woody densification reported in grasslands (Wigley et al. 2010; Estell et al. 2012). Therefore, management of the invaded landscape remains a challenge in a context of global environmental changes associated with increasing atmospheric $\mathrm{CO}_{2}$ concentration.

Globally, most rangelands become dominated by a new combination of plants and animals due to anthropogenic activities forming what has been referred to as 'novel ecosystems' or 'emerging ecosystems' (Hobbs et al. 2014). A 'novel ecosystem' relates to a completely transformed socio-ecological system from its historical baseline due to human activities such that restoration of the original system may not be possible (Hobbs et al. 2009; Morse et al. 2014). An estimated $18 \times 10^{4} \mathrm{~km}^{2}$ of land in South Africa is infested by IAPs (Kotzé et al. 2010) and thus transforming the landscape. In South Africa, grassland comprise about 27.9\% of the total area of biomes and is the second largest after the Savannah Biome (Van Wilgen et al. 2012). About 30\% of the South African Grassland Biome has been permanently modified (Mucina et al. 2006) and this affects livestock and wildlife production. Invasion by woody plants is one of the pervasive drivers of grassland transformation in South Africa and influences rangeland production. Although woody encroachment in grasslands means higher storage of carbon, the usefulness of this carbon in providing local ecosystems services is questionable. In areas where the forest markets are efficient, communities could easily sell the problematic IAPs such as Acacia mearnsii (black wattle) as timber to prospective buyers and money used for community development. However, in a context of weak market linkages for A. mearnsii such as in the rural areas of the former Transkei in the north Eastern Cape, the invasion may be even more disadvantageous to local farmers. Communal farmers have indicated a preference for grazing and cultivation rather than stands of $A$. mearnsii (Adam Perry, pers.comm). 
101 South Africa is implementing a Payment for Ecosystems Services (PES) programme to clear IAPs. This is done under the auspices of the Working for Water (WfW) programme at an annual cost of approximately US\$100 million (Turpie et al. 2008). The WfW programme is an extended public works programme that began in 1995 to clear land of IAPs since they adversely affect water resources and threaten ecological integrity (Van Wilgen et al. 2012). It also seeks to provide job opportunities, training and economic empowerment (Turpie et al. 2008). IAPs in South Africa are reported to have a very high total incremental water use compared to indigenous vegetation (Clulow et al. 2011) and it is believed that clearing therefore will salvage a significant proportion of water to maintain other ecosystem services (Van Wilgen et al. 2008; Meijninger and Jarmain 2014). To be successful, clearing of IAPs should be followed by effective regeneration of indigenous vegetation cover. From a rangelands production perspective, application of an effective post clearing management regime is required in order to improve the grass cover within the landscape and this can ensure that there is controlled runoff and groundwater recharge. It is envisaged that if more water is salvaged and retention time is increased, then more productive local desirable vegetation is likely to grow particularly if re-vegetation is done (Holmes et al. 2008). From a grazing perspective, this means higher grass production. Increased grass biomass invariably contributes to improving livestock and wildlife production in such areas.

Rangelands provide a number of ecosystem services such as forage production, water supply, habitat, biodiversity, carbon sequestration and recreation amongst others. In order to understand loss or gain of such ecosystem services as a result of $A$. mearnsii infestation in a given area, an appreciation of the magnitude of the infestation is vital. Hence, an investigation into the biophysical attributes of the components of these invaded landscapes related to the leaf area index (LAI), normalised difference vegetation index (NDVI) and aboveground biomass (AGB) could be useful. These vegetation attributes have direct implications on resources use (water, sunlight and minerals) and on the carbon sequestration ability by any given vegetation stand. This in turn influences the ability of an infested rangeland to produce ecosystems services required by local farmers. Therefore, from a rangeland management perspective, it will be prudent to understand how these vegetation attributes influence grass production which is important for local farmers.

It has been shown that clearing may not necessarily promote regeneration of indigenous vegetation in riparian areas and re-infestation by other invaders remains a distinct possibility (Holmes et al. 2008; Le Maitre et al. 2011; Simberloff et al. 2013) especially within the 
purview of global fertilization by carbon under elevated atmospheric $\mathrm{CO}_{2}$ concentrations. Van Wilgen et al. (2011) observed that where IAP eradication is impossible owing to the magnitude of the infestation, containment and impact reduction were viable strategies. Despite huge expenditure in clearing efforts in South Africa, only a small portion of infested areas have been cleared. Many studies have reported very little progress $(<10 \%)$ in some areas prioritized for clearing since the inception of the clearing programme in 1995 (Beater et al. 2008; Van Wilgen et al. 2012). We have also observed that since the inception of the clearing project in the northern Eastern Cape, there has been relatively little progress in terms of reduction in the total infestation. A preliminary assessment using recent QuickBird imagery (2000 compared to 2015) on land under communal tenure shows significant densification of existing infestations. The patches of successfully cleared lands are mainly 'low hanging fruit' situated on land under free-hold tenure or on communal land with ease of access (for example, adjacent to roads and villages), and the spatial extent seldom exceeds 5 ha. In addition, there is seldom evidence of 'follow up' after the initial clearing. As a consequence, there is need for innovative strategies to expedite the clearing process or to take advantage of the invasion to enhance net benefits to the community. Opportunities include enhancing grass production for farmers and promoting the water and biodiversity benefits envisaged by WfW. It has been recognised that the implementation of a strategy to deal with IAPs should take place within the broader framework of adaptive management (Van Wilgen et al. 2011; Sayre et al. 2012). This suggests that policies could be implemented experimentally, with a desire to learn and promote continuous improvement in the management of severe problems such as IAPs. The aim of this study was to understand the biophysical properties of $A$. mearnsii in grasslands as they relate to grass production and to explore possible alternative management options. It is envisaged that this understanding could form the basis for future research on management of infested rangelands.

\section{Materials and methods}

\section{Study area}

Three quaternary catchments in the Kei and the Umzimvubu Primary Catchments were selected for the study (Figure 1). These were quaternary catchments S50E, T12A and T35B which represent areas where IAPs are a known threat and some clearing by WfW has taken place. Catchments S50E and T12A are located within the Emalahleni and Sakhisizwe Local Municipalities (Chris Hani District Municipality). Catchment S50E supplies the Ncora dam 
on the Tsomo River. The Ncora dam was established in 1975 and has a capacity of $150 \times 10^{6}$ $\mathrm{m}^{3}$ and a surface area of approximately $1392 \mathrm{ha}$. The land tenure is exclusively leasehold, with approximately 15 villages occurring in this quaternary catchment. In quaternary catchment T12A there is a history of both leasehold and freehold tenure, although the recent (post-1976) land re-distribution programme has seen the creation of several new leasehold (communal) villages from previous freehold farms. Across both catchments, the main economic activities are livestock production (cattle, sheep, goats and poultry) and rain-fed annual crop production. T35B is a quaternary catchment for the Pot River, a tributary of the Mzimvubu River. The land tenure system within this quaternary is predominantly freehold, with significant commercial forest plantations, dry land cultivation and livestock production off un-improved natural rangeland. Across all the study sites A. mearnsii is clustered in isolated patches $<1 \mathrm{~km}^{2}$.

\section{Methods}

\section{Estimation of A. mearnsii density}

Using Google Earth images, a total of nine sites that represented dense A. mearnsii stands were identified. With respect to quaternary catchments S50E and T12A, five and three sites respectively were identified. In quaternary catchment T35B there was only one patch of land that was densely invaded. Acacia mearnsii stand density was measured using the pointcentred-quarter (PCQ) method (Cottam and Curtis 1956; Bonham 1989). At each site, data were collected from three replicated points, making a total of 27 points across sites. Density sampling points were separated by a distance of $40 \mathrm{~m}$ and the replication of samples ensured that the derived densities were sufficient and representative of the stand. In general distance methods help to reveal connectedness or pattern within plant communities (Fidelibus and MacAller 1993). PCQ is a robust method that provides more data per sampling point than other distance methods (Cottam and Curtis 1956). Taking into consideration variations in stem characteristics across the invaded patches, three size classes based on the Diameter at Breast Height (DBH: $1-5 \mathrm{~cm}, 6-10 \mathrm{~cm}$ and 11-15 cm) were defined to determine the density of each class at selected points. Distances to the nearest individuals in each quadrat and in each size class were measured using a laser distance measure (Leica DISTO ${ }^{\mathrm{TM}} \mathrm{X} 310$ ). Only trees that were within $10 \mathrm{~m}$ of the sampling point were considered since beyond this, the laser beam was not visible in the $A$. mearnsii forest. The replication of sample points ensured that variation in tree density across the landscape was captured. 
Allometric equations are useful methods for determining biomass in a quick and nondestructive manner (Flombaum and Sala 2007; Kuyah et al. 2012; Chave et al. 2014), and have often been developed for biomass estimation in plantations. The possibility of developing allometric equations for trees growing outside the plantations has also been demonstrated (Kuyah et al. 2012; Paul et al. 2013; Chave et al. 2014). An allometric equation for predicting A. mearnsii biomass using DBH, developed by Paul et al. (2013) for the mesic (rainfall $>300 \mathrm{~mm}$ ) southern and eastern Australia, was applied in this study to predict biomass per hectare. The equation uses a power function which has a linear equivalent form: $\ln (\mathrm{y})=a^{\prime}+\mathrm{b} * \ln (\mathrm{x})+e^{\prime}$

where $\mathrm{y}$ is the aboveground biomass (AGB) $\mathrm{kg}$ tree ${ }^{-1}$, expressed on a dry weight basis and $\mathrm{x}$ is the stem diameter in centimetres $(\mathrm{cm}), a^{\prime}$ is the intercept and $\mathrm{b}$ is the scaling allometric exponent and $e^{\prime}$ is the error term. The adopted equation is as follows:

$\ln (y)=-2.02+2.46 * \ln (x)+0.157$

\section{Grass cover, LAI and NDVI measurements}

To evaluate local factors determining grass cover, sampling was informed by the land systems approach (Van der Merwe et al. 2015). Land systems are natural areas with a recurring pattern of topography, soils, vegetation, drainage and other physical features in relatively uniform climatic regimes. Therefore, land systems and their facets do not occur randomly but are systematically linked by geomorphologic processes, origin and water movement (Van der Merwe et al. 2015). In addition, land systems are not confined to one environmental factor but cover a whole range of the physical environment to the extent that it influences environmental potential. This broader outlook is necessary to better understand the influence of physical factors affecting grass production in areas infested by A. mearnsii in order to develop appropriate interventions. Based on the land systems approach, it is assumed that areas within a similar gradient should have more or less similar vegetation cover. Hence, a total of 46 sampling points were located across environmental gradients and A. mearnsii canopy LAI, grass cover and slope were measured. A total of 23, 15 and 8 points were located in quaternary catchments S50E, T12A and T35B respectively. The points were carefully chosen to cover diverse slope ranges and the total number of points was proportional to size of invaded patches in each quaternary catchment. We hypothesized that a particular black wattle canopy LAI and terrain slope combination militates grass production. 
236 Woody canopy LAI (usually dominated by $A$. mearnsii) was determined using an AccuPAR ceptometer model LP-80 PAR/LAI (Decagon Devices Inc., Pullman, Washington USA). The ceptometer determines the fraction of photosynthetically active radiation (fPAR) intercepted by the canopy, and uses a gap analysis algorithm to determine LAI (Butterfield and Malmstrom 2009). At each sampling point repeated (>5) recordings of LAI were performed to derive the mean value since each reading gives a slightly different result due to variations in solar incident radiation recorded by the instrument.

Normalized difference vegetation index (NDVI)

Landsat 8 Climate Data Record (CDR) Surface Reflectance data product images for the area were acquired for a scene closest to each sampling event (scene ID LC81690822015172LGN00) and an NDVI was produced from bands 4 and 5 using ArcGIS version ${ }^{\circledR} 10.2$ (ESRI, USA). NDVI values for pixels that coincided with sites, where stand density was assessed, were then extracted. Since the data varied and had no fixed values, Standard Major Axis (SMA) regression was performed to determine the relationship between NDVI and AGB at the 0.05 significance level. SMA tries to minimize the squared errors in both the $x$ and the $y$ values (Warton et al. 2006).

\section{Grass cover and slope measurements}

Grass cover was estimated at the point where LAI and slope were measured. At each sampling site, grass cover was determined below the $A$. mearnsii canopy using a $1.0 \mathrm{~m} \times 0.2$ m quadrat (Bonham 1989; Flombaum and Sala 2007). The quadrat was thrown three times around each sampling point and percentage cover was an ocular estimate based on the area covered by grass in order to derive an average percentage value. Three throws were found adequate during our pre-testing since the average estimated percentage cover did not change significantly beyond three throws on the small (area wise) sampling point. Ocular approaches using small quadrats improve the accuracy of cover estimates and are a quick way of sampling (Winkworth et al. 1962). The slope was measured using a laser distance measure (Leica DISTO ${ }^{\mathrm{TM}}$ X 310) in degrees. Subsequently, linear regressions were prepared to predict grass cover from slope and LAI individually and also from a combination of the two in order to determine critical thresholds required for viable grass production. In order to investigate 
critical levels for canopy LAI required to sustain viable grass cover, a generalized linear model using the logarithmic link function was fitted into the data.

\section{Results}

Estimated A. mearnsii density

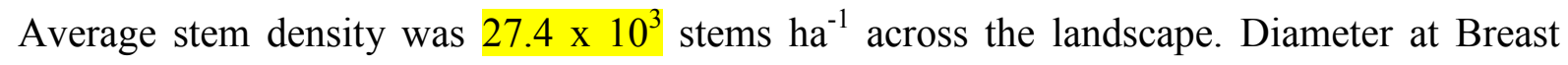
Height $(\mathrm{DBH})$ class 1 dominated the landscape and contributed $74 \%$ to mean density followed by class $2(16 \%)$ and lastly class $3(9 \%)$. Figure 2 shows the distribution of $A$. mearnsii density per class in the landscape. Absolute density ranged from $17.38 \times 10^{2}$ to $13.223 \times 10^{4}$ stems $^{-1} \mathrm{ha}^{-1}$. DBH class 1 density was significantly different from the other two classes $(\mathrm{p}<0.05)$ while classes 2 and 3 were not significantly different.

\section{Estimated standing biomass}

Mean AGB was estimated at 305 tonnes $\mathrm{ha}^{-1}$ with the biggest contributor to this biomass being DBH class 3. The proportion of DBH classes 1, 2 and 3 to total AGB was 10, 31 and $59 \%$ respectively. For DBH class 1, the highest estimated AGB was 196 tonnes $\mathrm{ha}^{-1}$ and the lowest was about 1.7 tonnes ha $^{-1}$ (Figure 3). With respect to DBH class 2, AGB ranged from 6 to 450 tonnes $\mathrm{ha}^{-1}$. The highest standing biomass in DBH class 3 was 984 tonnes ha ${ }^{-1}$ while the lowest was 14 tonnes $\mathrm{ha}^{-1}$. Predicted AGB differed significantly across the three DBH classes $(p<0.05$, Figure 3$)$. Absolute biomass ranged from 26 to 1117 tonnes ha $^{-1}$ across sites.

\section{Relationship between standing biomass, LAI and NDVI}

The relationship between NDVI and total AGB was significant $(\mathrm{p}<0.05)$ with NDVI explaining about $76 \%$ of total variation in AGB $\left(\mathrm{R}^{2}=0.77\right.$, Figure 4$)$. There was no autocorrelation between adjacent residuals as shown by a Durbin-Watson statistic of 2 ( $\mathrm{p}<$ 0.05 ) and as such the null hypothesis of non-auto correlated errors was accepted. In general, Durbin-Watson statistic values of between 1.5 and 2.5 mean that there is no autocorrelation in the sample while values approaching zero (0) indicate positive autocorrelation and values toward 4 indicate negative autocorrelation. LAI and NDVI had a strong linear relationship in this study $\left(\mathrm{R}^{2}=0.73\right.$, Durbin-Watson statistic $=2.2$, Figure 5$)$.

\section{LAI thresholds for grass production}


The $A$. mearnsii LAI recorded ranged from 0.14 to 5.12. Terrain slope ranged from $3.2^{\circ}$ to $26.1^{\circ}$ indicating a very wide environmental gradient where sampling was conducted. Acacia mearnsii LAI and grass cover had a significant relationship $(\mathrm{p}<0.05)$ although LAI explained only about $38 \%$ of the variation in the grass cover $\left(\mathrm{R}^{2}=0.4\right)$. Figure 6 shows a grass cover against LAI plot which gives insights into the LAI values that have to be maintained to allow viable grass production. A generalized linear model using the logarithmic link function was fitted into the data. This model was found to be ideal since grass cover decreases quickly and then levels out at zero with increasing LAI. For example, to sustain a $50 \%$ grass cover in infested areas, $A$. mearnsii LAI should be maintained at about 0.72 and LAI of about 0.12 could sustain $100 \%$ grass cover. In addition, as soon as the LAI approaches 2.1, grass cover drops to about 10\% (Figure 6). Using multiple linear regression to predict grass cover from a combination of LAI and slope, the model explained about $37 \%$ of the total variation in grass cover $\left(\mathrm{R}^{2}=0.4\right)$ and the association was statistically significant $(p<0.05)$. The relationship between the terrain slope and grass cover was weak with slope only explaining about $2.6 \%$ variation in grass cover. Slope accounted for about $18.1 \%$ variation in $A$. mearnsii LAI across the environmental gradients and this was statistically significant $(\mathrm{p}<0.05)$.

\section{Discussion}

\section{Density and standing biomass}

Acacia mearnsii is well established in the study area as evidenced by the presence of different cohorts of varying size classes. Despite clearing by the WfW programme, and use by the local communities for house construction and wood fuel amongst other uses, the densification of invasion continues. This is also evidenced by very high variability in density and AGB in different DBH cohorts across the sites, suggesting that $A$. mearnsii distribution was highly inconsistent, probably due to the varying intensity of use, clearing and historical planting as woodlots. DBH class 3 contributed a significantly larger proportion of AGB than each of the other two classes and this was consistent with results from elsewhere (Sist et al. 2014; Kuyah and Rosenstock 2015). Higher density for small stems confirms that A. mearnsii densification is taking place in the study sites.

The adopted equation for predicting AGB is robust as it was species specific and the data used was derived in a region with similar conditions as our case study. Chave et al. (2005) recommended that including wood density and height in allometric equations resulted in 
more accurate AGB estimates especially in complex environments where mixed species regressions should be used. However, this study was concerned with a single species and Paul et al. (2013) recorded high model efficiency indices for equations that used DBH only, suggesting that the relationship was credible and that models using DBH only are robust in single species areas and hence, our AGB results should be accurate. In the selected quaternary catchments, particularly S50E and T12A, A. mearnsii was freely available as a common property resource but there were no communal institutions for its management. Many negative aspects of $A$. mearnsii related to water use and biodiversity loss have been reported (for example, Marais and Wannenburgh 2008; Turpie et al. 2008; Van Wilgen et al. 2008; Meijninger and Jarmain 2014) and dense stands are reportedly a haven for criminals (pers.comm. with community members). On the other hand, A. mearnsii is also crucial for fuel and supports livelihoods (Kull et al. 2011; Van Wilgen et al. 2011; Simberloff et al. 2013). Within the broader context of global change, it is also crucial as a carbon sink. Extensive livestock and crop farming are major livelihood activities in the study sites. Therefore, heavy infestation leads to a concomitant loss of land available for key livelihood activities. With the density of infestations reported in this paper, it is not surprising that there has been little progress in reducing the invaded area in the study catchments. In addition, there has seldom been any follow-up after clearing. Acacia mearnsii clearing efforts have revolved around clear felling the entire stand and leaving most of the residues to rot in situ. Although Holmes et al. (2008) recommended clear fell and removal of wood as an effective approach, with the very high densities reported here, it may not be a viable long term policy. McConnachie et al. (2012) reported that despite huge financial expenditure, the current IAPs control efforts in South Africa were insufficient to stop their spread. For example, Van Wilgen et al. (2012) found that since 1995 only $8 \%$ of the estimated A. mearnsii invaded land has been treated in the Savannah and Grassland Biomes.

The AGB reported in this paper may be economically viable if communities are properly linked to the market to sell A. mearnsii. This would mean identifying prospective buyers of the resource in the forestry and chip board industry to do business with the communities. The local baseline data generated in this paper, when combined with GIS estimates of the spatial extent of invasion, could be vital in predicting the economic value of the resource and may give communities an opportunity to negotiate trade contracts from an informed position. Within the broader context of reducing emissions from all land uses (REALU, Kuyah et al. 2012), the effect of $A$. mearnsii on carbon sequestering can now be quantified in the selected area. 


\section{LAI-NDVI and standing biomass relationships}

Based on the relationships established in this paper, it should theoretically be possible to confidently predict A. mearnsii LAI from NDVI. Although, a strong relationship was established to predict AGB from NDVI, it was only applicable over a very narrow LAI, NDVI and time range. Therefore, given that $A$. mearnsii is evergreen, it might be prudent to undertake further studies over a year to discern whether this relationship persists throughout the year. Other studies have found that LAI and NDVI were useful predictors of biomass before saturation point is reached (Ghebremicael et al. 2004; Wessels et al. 2006; Reddersen et al. 2014). We did not observe any NDVI saturation in this study. Further, the seasonal summation of NDVI ( $\sum$ NDVI) has often been found to correlate very well with biomass and several studies have used it as a proxy for AGB (for example, Fensholt et al. 2013; Dardel et al. 2014). Although terrain slope accounted for only $18.1 \%$ of the total variation in $A$. mearnsii LAI, the relationship was significant and this was indicative of water availability at plant root zones. This was not surprising since it is expected that water should be more available in gently sloping areas as it collects at such points from the steep slopes.

\section{Managing A. mearnsii invaded rangelands}

The use of a landscape based sampling technique informed by terrain slope ensured that diverse landscapes were covered to investigate the potential for grass production in $A$. mearnsii infested areas. It is well established that local physical landscape factors such as nutrients, aspect, runoff and run-on dynamics are critical in modulating grass production. Therefore, sampling across a very wide environmental gradient ensured that the influence of these factors did not colour our results. From the sampling conducted (terrain slope ranging from $3.2^{\circ}$ to $26.1^{\circ}$ ), slope was not a constraint to grass production. This was confirmed statistically that the relationship between terrain slope and grass cover was weak and insignificant. Hence, the data rejected our preliminary hypothesis that at critical terrain slope and $A$. mearnsii LAI thresholds, grass production was inhibited. Combining slope and $A$. mearnsii LAI to predict grass cover did not improve the model. This means that LAI was more influential in determining grass production than terrain slope.

Results from this study suggest that as soon as canopy LAI approaches 2.1, grass cover drops to about $10 \%$ and maintaining a canopy LAI of 0.72 will make about $50 \%$ more grass cover available for grazers. This was consistent with results by Ansley et al. (2013) who found that maintaining woody cover below $30 \%$ enhanced growth of productive $\mathrm{C}_{4}$ grasses. Therefore, from a grazing perspective, it is possible for grass production to be viable in A. mearnsii 
invaded areas. In order to promote grass production, it will be essential to reduce LAI of $A$. mearnsii through ecological thinning. Ecological thinning is the selective removal of stems in woody ecosystems to restore historical or ecologically desirable ecosystem structure and processes (Dwyer et al. 2010). It is well established that A. mearnsii has allelopathic effects (Fatunbi et al. 2009) hence thinning could help to reduce these and subsequently, it may promote multiple ecosystem services such as grass production and carbon sequestration by the woody A. mearnsii amongst others.

Ecological thinning as a management approach could link very well with the "novel ecosystem' paradigm. It can be postulated that the IAP invasions in socioecological conditions reported in this paper have transformed the landscape into a 'novel ecosystem' In a context of global environmental changes associated with climate change, ecological restoration of such rangelands could be very difficult (Estell et al. 2012). Therefore, when it is no longer socially, economically and ecologically possible to restore an ecosystem, it is prudent to explore alternative targets that will inadvertently deliver requisite ecosystem services (Monaco et al. 2012). From this perspective, embracing the 'novel ecosystems' approach may be a viable strategy to salvage value from transformed rangelands. About 70 Australian acacia species have been introduced in South Africa since 1830s (Van Wilgen et al. 2011) and most of them have increasingly become invasive. Therefore, it may be pragmatic to embrace the 'novel ecosystem' paradigm to the management of IAPs such as Australian acacias. Coffman et al. (2014) found that shrub clearing as a form of restoring grasslands in the Chihuahuan Desert did not restore the ecosystem but produced a "novel ecosystem'. Therefore, there is a distinct possibility that such a response may occur in other grasslands, hence entrenching the need for adopting this new paradigm. However, some scientists are very sceptical of the 'novel ecosystems' approach since they believe it encourages poor environmental management (for example, Simberloff et al. 2013; Murcia et al. 2014). Nevertheless, the 'novel ecosystems' paradigm does not discount traditional approaches such as ecological restoration and rehabilitation but strives for an appropriate mix of old and emerging approaches (Hobbs et al. 2009; Hobbs et al. 2014). Therefore, it is consistent with the adaptive management approach for intractable problems and may be worth embracing with respect to management of IAPs.

Literature seems to imply that some IAPs will not be eradicated in the foreseeable future owing to economic costs attached to treatment efforts and environmental factors modulating their propagation (Holmes et al. 2008; Le Maitre et al. 2011; Van Wilgen et al. 2011). While biological and chemical control maybe promising, uncertainties on their ecosystem impacts 
deter their widespread adoption. The primary motivation for clearing IAPs in South Africa is to salvage water, restore structure and functioning of natural ecosystems and to increase the productivity of the land (Holmes et al. 2008). Given the density reported in this paper and the pace of clearing, these objectives have remained largely elusive in our study sites. Therefore, it can be submitted that preoccupation with restoring ecosystems to an earlier state may not be pragmatic for South Africa, particularly in the rangelands. As such, it becomes prudent to rethink about such biological invasions or exploit their beneficial services and adopt ecological thinning as an adaptive management strategy.

\section{Conclusions}

Acacia mearnsii is far from being eradicated since it is still spreading as evidenced by many small stemmed trees across the sampling sites The high biomass reported in this work can provide business opportunities through selling the $A$. mearnsii stands to the forestry industry and in the form of carbon credits under the auspices of REALU. Grass production can still be viable in areas infested by $A$. mearnsii. Canopy cover of $A$. mearnsii was the most critical variable, since beyond specific LAI thresholds, grass production was impeded. In socioecological settings such as reported in this study, reducing A. mearnsii canopy LAI through thinning could be critical to enhance multi-benefits of the invaded landscape such as grazing and carbon sequestration. The relationships between NDVI and LAI developed in this paper can be used to target areas for thinning. This may be crucial in improving livestock production in such socioecological landscapes. Although thinning could invariably mitigate allelopathic effects, more intensive experimental work still needs to be conducted to understand the response of South African grasslands to canopy thinning. This will enable communities to get more value out of the invaded landscapes.

Acknowledgements - This work was supported by the South African Water Research Commission Project K5/2400/4, NRF THRIP and Red Meat Research Development-SA through grants to the ARC. The Working for Water programme is also acknowledged for GIS data.

\section{References}


Ansley RJ, Mirik M, Heaton CB, Wu XB. 2013. Woody Cover and Grass Production in a Mesquite Savanna: Geospatial Relationships and Precipitation. Rangeland Ecology and Management 66: 621-633.

Beater MM, Garner RD, Witkowski ETF. 2008. Impacts of clearing invasive alien plants from 1995 to 2005 on vegetation structure, invasion intensity and ground cover in a temperate to subtropical riparian ecosystem. South African Journal of Botany 74: 495507.

Bonham CD. 1989. Measurements for Terrestrial Vegetation. New York: Wiley.

Butterfield HS, Malmstrom CM. 2009. The effects of phenology on indirect measures of aboveground biomass in annual grasses. International Journal of Remote Sensing 30:3133-3146.

Chave J, Réjou-Méchain M, Búrquez A, Chidumayo E, Colgan MS, Delitti WBC, Duque A, Eid T, Fearnside PM, Goodman RC, Henry M, Martínez-Yrizar A, Mugasha WA, MullerLandau HC, Mencuccini M, Nelson BW, Ngomanda A, Nogueira EN, Ortiz-Malavass IE,Pélissier R, Ploton P, Ryan CM, Saldarriaga JG,Vieilledent G. 2014. Improved allometric models to estimate the aboveground biomass of tropical trees. Global Change Biology 20: 3177-3190.

Chave J, Andalo C, Brown S, Cairns MA, Chambers JQ, Eamus D, Fölster H, Fromard F, Higuchi N, Kira T, Lescure JP, Nelson BW, Ogawa H, Puig H, Riéra B, Yamakura T. 2005. Tree allometry and improved estimation of carbon stocks and balance in tropical forests. Oecologia 145: 87-99.

Clulow AD, Everson CS, Gush MB. 2011. The Long Term Impact of Acacia mearsii Trees on Evapotranspiration, Stream Flow and Ground Water Resources. WRCreport no. TT505/11. Pretoria: Water Research Commission.

Coffman JM, Bestelmeyer BT, KellyJF, Wright TF, Schooley RL. 2014. Restoration practices have positive effects on breeding bird species of concern in the Chihuahuan Desert. Restoration Ecology 22: 336-344.

Cottam G, Curtis JT. 1956. The use of distance measures in phytosociological sampling. Ecology 37: 451-460.

Dardel C, Kergoat L, Hiernaux P, Grippa M, Mougin E, Ciais P, Nguyen CC. 2014. Rainuse-efficiency: what it tells us about the conflicting Sahel greening and Sahelian paradox. Remote Sensing 6: 3446-3474. 
Dwyer JM, Fensham R, Buckley YM. 2010. Restoration thinning accelerates structural development and carbon sequestration in an endangered Australian ecosystem. Journal of Applied Ecology 47: 681-691.

Estell RE, Havstad KM, Cibils AF, Fredrickson EL, Anderson DM, Schrader TS, James DK. 2012. Increasing shrub use by livestock in a world with less grass. Rangeland Ecology and Management 65: 553-562.

Fatunbi AO, Dube S, Yakubu MT, Tshabalala T. 2009. Allelopathic potential of Acacia mearnsii De Wild. World Applied Sciences Journal 7:1488-1493.

Fensholt R, Rasmussen K, Kaspersen P, Huber S, Horion S,Swinnen E. 2013. Assessing Land Degradation/Recovery in the African Sahel from Long-Term Earth Observation Based Primary Productivity and Precipitation Relationships. Remote Sensing 5: 664686.

Fidelibus MW, MacAller RT. 1993. Methods for plant sampling. Report to the California Department of Transportation. Available: http://www.sci.sdsu.edu/SERG/techniques/mfps.html [accessed 21 February 2016].

Flombaum PÃ, Sala OE. 2007. A non-destructive and rapid method to estimate biomass and aboveground net primary production in arid environments. Journal of Arid Environments 69: 352-358.

Ghebremicael ST, Smith CW, Ahmed FB. 2004. Estimating the leaf area index (LAI) of black wattle from Landsat ETM + satellite imagery. Southern African Forestry Journal 201: 3-12.

Hobbs RJ, Higgs E, Harris JA. 2009. Novel ecosystems: implications for conservation and restoration. Trends in Ecology and Evolution 24: 599-605.

Hobbs RJ, Higgs ES, Harris JA. 2014. Novel ecosystems: concept or inconvenient reality? A response to Murcia et al. Trends in Ecology and Evolution 29: 645-646

Holmes PM, Esler KJ, Richardson DM, Witkowski ETF. 2008. Guidelines for improved management of riparian zones invaded by alien plants in South Africa. South African Journal of Botany 74: 538-552.

Kotzé I, Beukes H, Van den Berg E, Newby T. 2010. National invasive alien plant survey. Report No. GW/A/2010/21. Pretoria: Agricultural Research Council, Institute for Soil, Climate and Water.

Kull CA, Shackleton CM, Cunningham PJ, Ducatillon C, Dufour-Dror JM, Esler KJ, Friday JB, Gouveia AC, Griffin AR, Marchante E, Midgley SJ, Pauchard A, Rangan H, Richardson DM, Tony R, Jacques T, Lauren SU, von Maltitz GP, Zenni DR, Zylstra MJ. 
2011. Adoption, use and perception of Australian acacias around the world. Diversity and Distributions 17: 822-836.

Kuyah S, Rosenstock TS. 2015. Optimal measurement strategies for aboveground tree biomass in agricultural landscapes. Agroforestry Systems 89: 125-133.

Kuyah S, Dietz J, Muthuri C, Jamnadass R, Mwangi P, Coe R, Neufeldt H. 2012. Allometric equations for estimating biomass in agricultural landscapes: I. Aboveground biomass. Agriculture Ecosystems and Environment 158: 216-224.

Le Maitre DC, Gaertner M, Marchante E, O' Farrell PJ, Holmes PM, Rogers M, Blanchard R, Blignaut J, Richardson DM. 2011. Impacts of invasive Australian acacias : implications for management and restoration. Diversity and Distributions 17: 1015-1029.

Marais C, Wannenburgh AM. 2008. Restoration of water resources (natural capital) through the clearing of invasive alien plants from riparian areas in South Africa - costs and water benefits. South African Journal of Botany 74: 526-537.

McConnachie MM, Cowling RM, van Wilgen BW, McConnachie DA. 2012. Evaluating the cost-effectiveness of invasive alien plant clearing : a case study from South Africa. Biological Conservation 155: 128-135.

Meijninger WML, Jarmain C. 2014. Satellite-based annual evaporation estimates of invasive alien plant species and native vegetation in South Africa. Water SA 40: 95-108.

Monaco TA, Jones TA, Thurow TL. 2012. Identifying rangeland restoration targets: an appraisal of challenges and opportunities. Rangeland Ecology and Management 65: 599-605.

Morse NB, Pellissier PA, Cianciola EN, Brereton RL, Sullivan MM, Shonka NK, Wheeler TB, McDowell WH. 2014. Novel ecosystems in the Anthropocene: a revision of the novel ecosystem concept for pragmatic applications. Ecology and Society 19: 12.

Mucina L, Hoare BD, Lötter MC, du Preez PJ, Rutherford MC, Scott-Shaw RC, Bredenkamp GJ, Powrie LW, Scott L, Camp KGT, Cilliers SS, Bezuidenhout H, Mostert TH, Siebert SJ, Winter PJD, Burrows JE, Dobson L, Ward RA, Stalmans M, Oliver EGH, Siebert F, Schimdt E, Kobisi K, Kose L. 2006. The Grassland Biome. In: Mucina L, Rutherford MC (eds), The vegetation of South Africa, Lesotho and Swaziland. Strelitzia 19. Pretoria: South African National Boidiversity Institute. pp 348-437.

Murcia C, Aronson J, Kattan GH, Moreno-Mateos D, Dixon K, Simberloff D. 2014. A critique of the "novel ecosystem" concept. Trends in Ecology and Evolution 29: 548553. 
Paul KI, Roxburgh SH, England JR, Ritson P, Hobbs T, Brooksbank K, Raison JR, Larmour SJ, Murphy S, Norris J, Neumann C, Lewis T, Jonson J, Carter LJ, McArthur G, Barton C, Rose B. 2013. Development and testing of allometric equations for estimating aboveground biomass of mixed-species environmental plantings. Forest Ecology and Management 310: 483-494.

Reddersen B, Fricke T, Wachendorf M. 2014. A multi-sensor approach for predicting biomass of extensively managed grassland. Computers and Electronics in Agriculture 109: $247-260$.

Sayre NF, deBuys W, Bestelmeyer BT, Havstad KM. 2012. "The range problem" after a century of rangeland science: new research themes for altered landscapes. Rangeland Ecology and Management 65: 545-552.

Simberloff D, Martin JL, Genovesi P, Maris V, Wardle DA, Aronson J, Courchamp F, Galil B, García-Berthou E, Pascal M, Pyšek P, Sousa R, Tabacchi E, Vilà M. 2013. Impacts of biological invasions: what's what and the way forward. Trends in Ecology and Evolution 28: 58-66.

Sist P, Mazzei L, Blanc L, Rutishauser E. 2014. Large trees as key elements of carbon storage and dynamics after selective logging in the Eastern Amazon. Forest Ecology and Management 318: 103-109.

Turpie JK, Marais C, Blignaut JN. 2008. The working for water programme: evolution of a payments for ecosystem services mechanism that addresses both poverty and ecosystem service delivery in South Africa. Ecological Economics 65: 788-798.

Van der Merwe H, Bezuidenhout H, Bradshaw PL. 2015. Landscape unit concept enabling management of a large conservation area: a case study of Tankwa Karoo National Park, South Africa. South African Journal of Botany 99: 44-53.

Van Wilgen BW, Forsyth GG, Le Maitre DC, Wannenburgh A, Kotzé JDF, Van den Berg E, Henderson L. 2012. An assessment of the effectiveness of a large national-scale invasive alien plant control strategy in South Africa. Biological Conservation 148: 28-38.

Van Wilgen B, Dyer C, Hoffmann JH, Ivey P, Le Maitre DC, Moore JL, Wilson JRU. 2011. National-scale strategic approaches for managing introduced plants: insights from Australian acacias in South Africa. Diversity and Distributions 17: 1060-1075.

Van Wilgen BW, Reyers B, Le Maitre DC, Richardson DM, Schonegevel L. 2008. A biomescale assessment of the impact of invasive alien plants on ecosystem services in South Africa. Journal of Environmental Management 89: 336-349. 
Warton DI, Wright IJ, Flster DS, Westoby M. 2006. Bivariate line-fitting methods for allometry. Biological Review 81: 259-291.

600

Wessels KJ, Prince SD, Zambatis N, MacFadyen S, Frost PE. Van Zyl D. 2006. Relationship

601 between herbaceous biomass and $1-\mathrm{km}^{2}$ Advanced Very High Resolution Radiometer

602 (AVHRR) NDVI in Kruger National Park, South Africa. International Journal of Remote Sensing 27: 951-973.

604

Wigley BJ, Bond WJ, Hoffman MT. 2010. Thicket expansion in a South African savanna 605 under divergent land use: local vs. global drivers? Global Change Biology 16: 964-976.

Winkworth RE, Perry RA, Rossetti CO. 1962. A Comparison of methods of estimating plant

607 cover in an arid grassland community. Journal of Range Management 15: 194-196.

608

609

\section{List of figures}

610

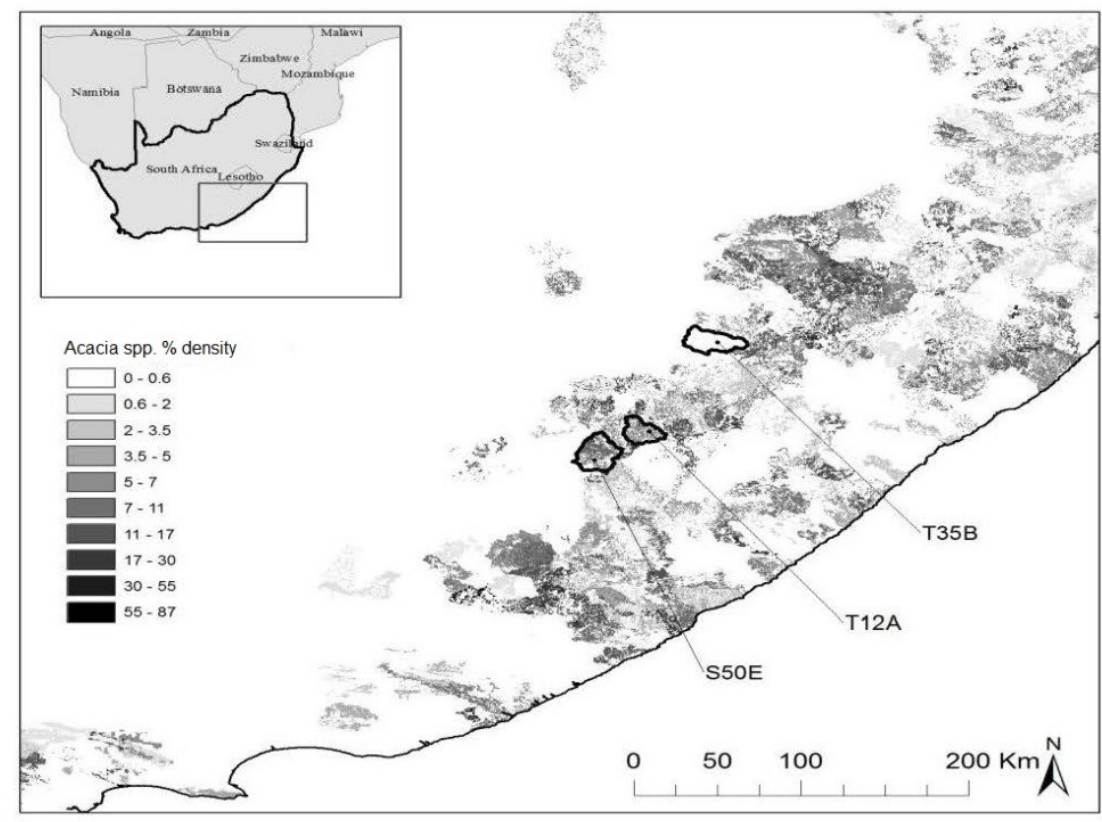

612 Figure 1: Map of the percentage density of Acacia mearnsii (black wattle) and three

613 quaternary study sites (S50E, T12A and T35B) in the Eastern Cape (adapted from Kotzé et 614 al. 2010). 


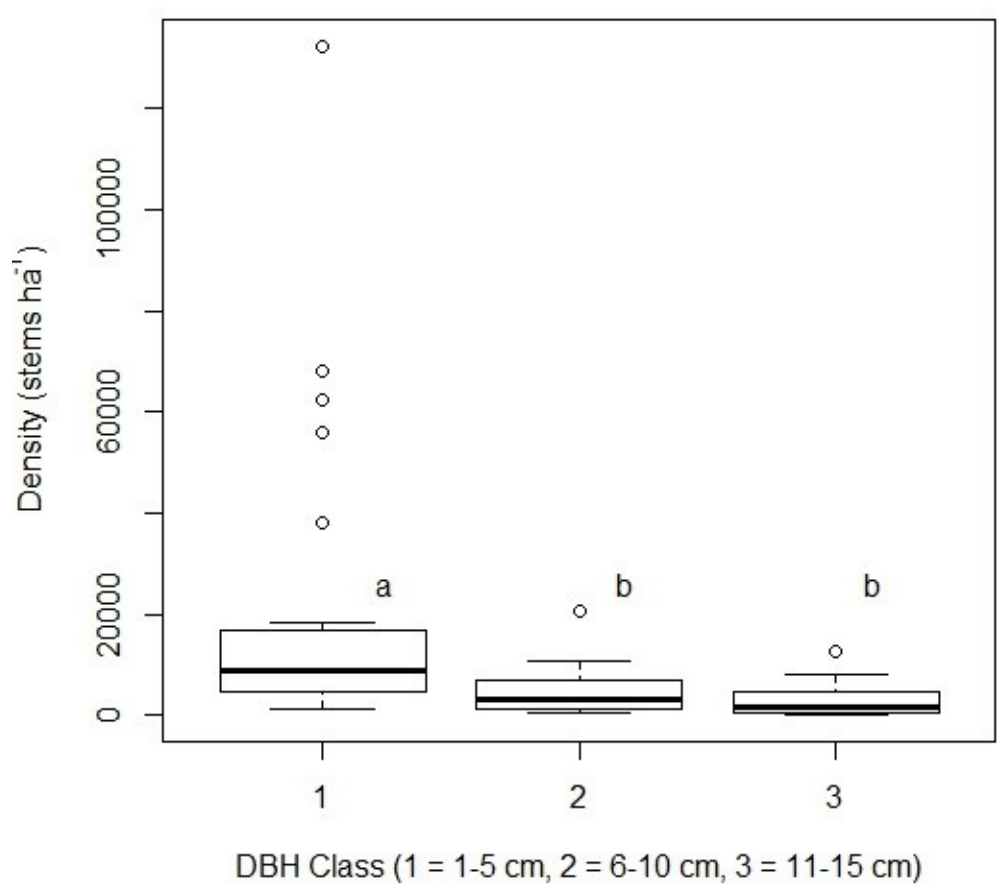

615

616 Figure 2: Variation in stem density for Acacia mearnsii in each Diameter at Breast Height

$617(\mathrm{DBH})$ class. $1=\mathrm{DBH}$ class $1(1-5 \mathrm{~cm}), 2=$ DHB class $2(6-10 \mathrm{~cm})$ and $3=\mathrm{DBH}$ class 3

$618(11-15 \mathrm{~cm})$. Letters shared in common between or among the categories indicate no

619 significant differences.

620

621 


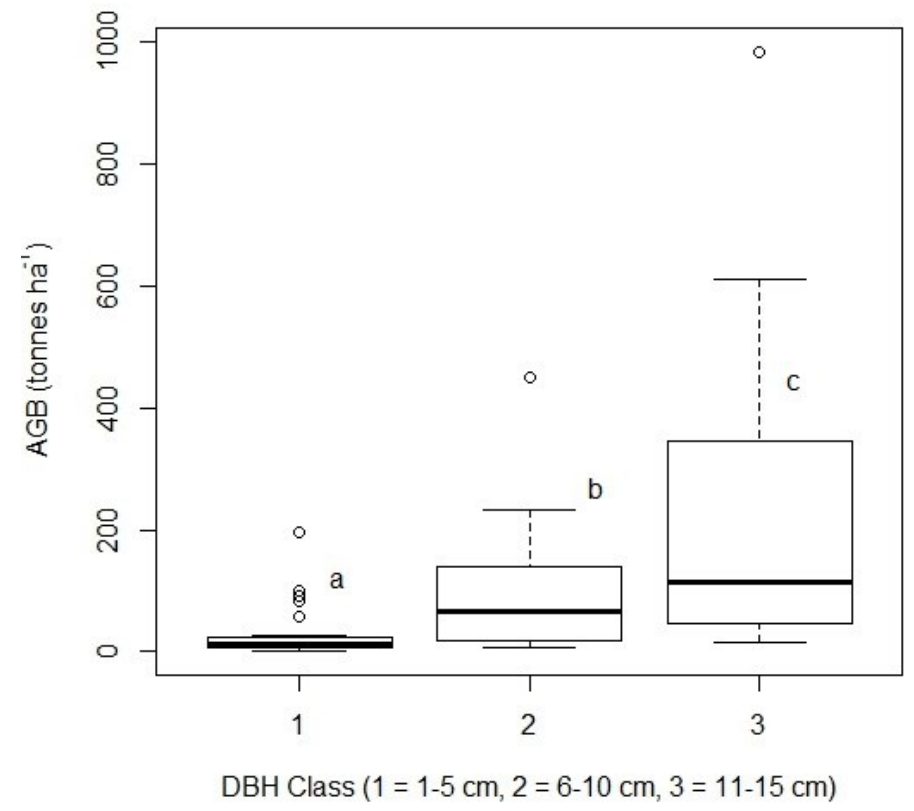

622

623 Figure 3: Variation in Aboveground biomass (AGB) for Acacia mearnsii in each Diameter at 624 Breast Height $(\mathrm{DBH})$ class. $1=\mathrm{DBH}$ class $1(1-5 \mathrm{~cm}), 2=$ DHB class $2(6-10 \mathrm{~cm})$ and $3=$ 625 DBH class $3(11-15 \mathrm{~cm})$. Letters shared in common between or among the categories indicate 626 no significant differences.

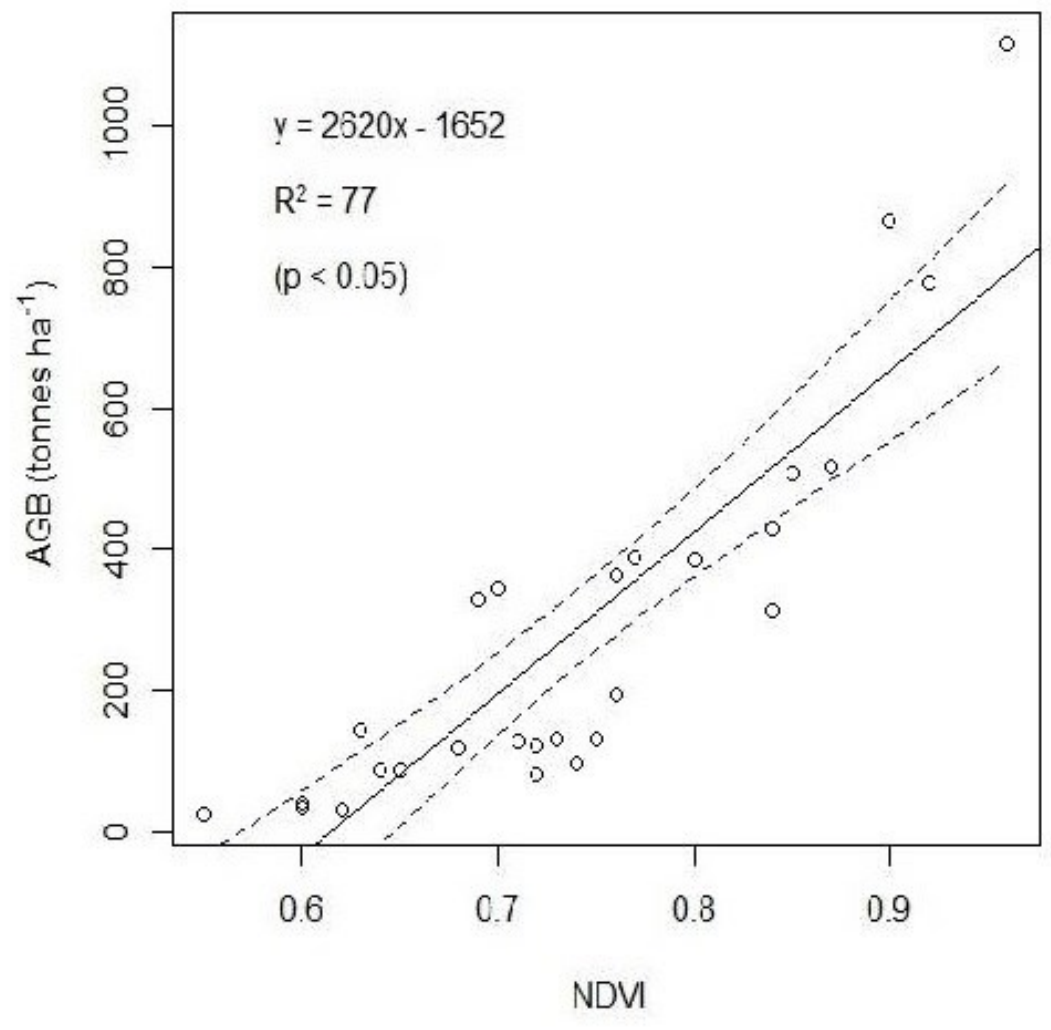


629 Figure 4: The relationship between Normalized Difference Vegetation (NDVI) and 630 aboveground biomass (AGB) for Acacia mearnsii with 95\% confidence interval across the 631 landscape.

632

633

634

635

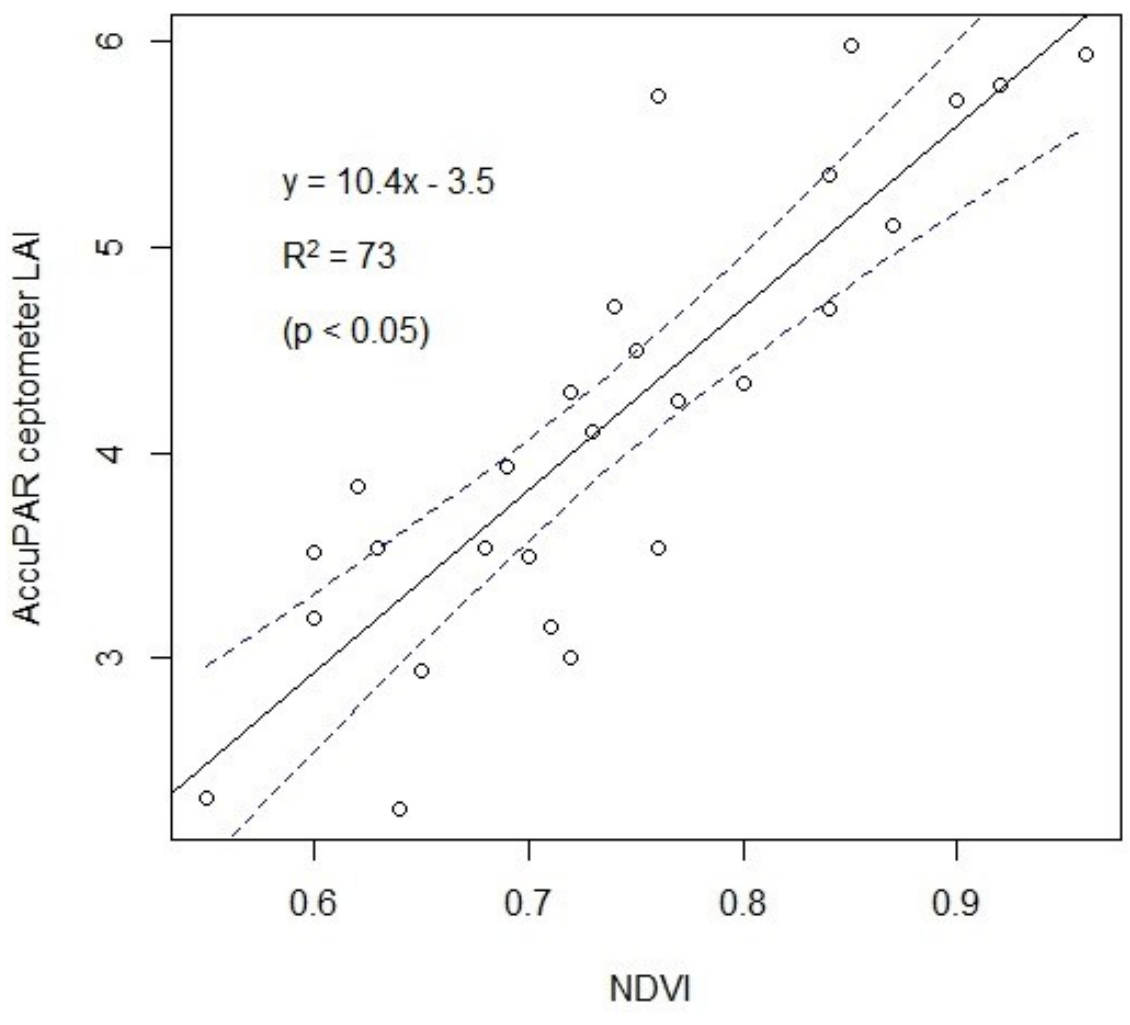

637 Figure 5: The relationship between Normalized Difference Vegetation (NDVI) and 638 AccuPAR ceptometer Leaf Area Index (LAI) of Acacia mearnsii with 95\% confidence 639 interval across the landscape. 


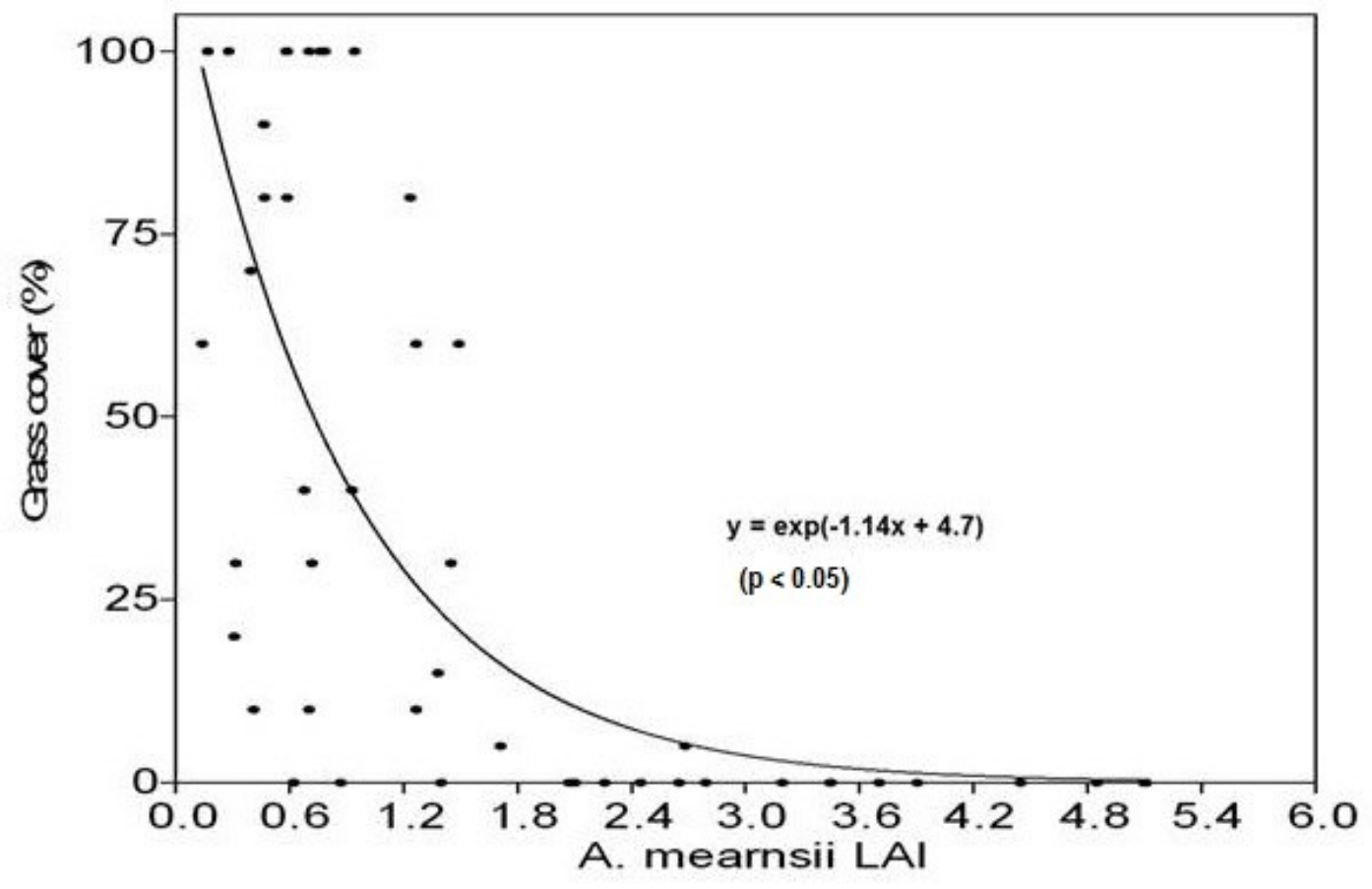

640

641

642 Figure 6: Relationship between Acacia mearnsii Leaf Area Index (LAI) anden grass cover 643 percentage across the landscape.

644

645 